\title{
PERAN ETIKA PROFESI HUKUM \\ TERHADAP UPAYA PEMBERANTASAN KEJAHATAN DAN PENANGGULANGAN KEJAHATAN PROFESI
}

\author{
Pudjo Utomo \\ Fakultas Hukum Universitas Wahid Hasyim \\ pudjoutomo@unwahas.ac.id
}

\begin{abstract}
ABSTRAK
Penelitian bertujuan mengetahui bagaimana peran etika profesi hukum dalam upaya pemberantasan kejahatan, dan bagaimana efektivitas etika profesi hukum dalam menanggulangi kejahatan yang timbul di lingkungan profesional.

Menggunakan metode penelitian kepustakaan (library research), yaitu metode yang digunakan dengan cara mempelajari buku literatur, peraturan perundang-an dan bahan-bahan tertulis lain yang berhubungan dengan materi pembahasan. Diperoleh simpulan bahwa supaya kode etik berfungsi dengan baik, kode etik harus menjadi self regulation (pengaturan diri) dari profesi dan pelaksanaannya diawasi terus menerus.
\end{abstract}

Kata kunci: EtikaProfesi, Kode Etik, Penanggulangan Kejahatan Profesi.

\section{PENDAHULUAN}

\section{A. Latar belakang}

Negara dan hukum yang dicita-citakan, seringkali tidak berdaya untuk menahan arus kepentingan sebagian kelompok orang yang pada gilirannya mengorbankan hak-hak rakyat, yang pada hakikatnya mengorbankan misi suci hukum itu sendiri. Hukum dalam banyak hal, seringkali bermetamorfosis menjadi legally institution, the arbitrariness, punishment institution dan seeker of justice. Implikasi dari fallacy hukum tersebut adalah porak porandanya sistem hukum nasional. Peran penegak hukum sangat menentukan untuk mengembalikan kepercayaan masyarakat terhadap hukum. Pada dasarnya, penegakan hukum adalah kegiatan menyerasikan hubungan nilai-nilai yang terjabarkan dalam kaidah-kaidah, pandangan-pandangan yang mantap dan mengejawantahkannya 
dalam sikap, tindak sebagai serangakaian penjabaran nilaitahap akhir untuk menciptakan kedamaian pergaulan hidup. ${ }^{24}$

Penegakan hukum hanya dapat terlaksana apabila berbagai dimensi kehidupan hukum selalu menjaga harmonisasi (keselarasan, keseimbangan dan keserasian) antara moralitas sosial, moralitas kelembagaan dan moralitas warga negara yang didasarkan pada nilai-nilai aktual di dalam masyarakat. Dengan demikian kebersamaan sangat dibutuhkan tidak hanya untuk membuat ramburambu pergaulan nasional, melainkan juga penegakannya. ${ }^{25}$

Dalam kerangka demikian keberadaannya terlihat sebagai tuntutan yang telah melahirkan kode etik (code of conduct). Standar-standar dalam code of conduct dapat dijadikan sarana untuk menentukan apakah telah terjadi malapraktek profesional atau tidak. Dapat dikatakan telah terjadi malapraktek apabila seorang profesional dalam menjalankan tugas dan kewajibannya telah melakukan tindakan yang tidak profesional di bawah standar atau sub-standard profesinya, menimbulkan kerugian (damage) terhadap orang lain sebagai akibat perbuatannya. $^{26}$

Dalam Code of Conduct for Law Enforcement Officials, Article 1, menentukan "...law enforcement officials shall at all times fulfil the duty imposed upon them by law, by serving the community and by protecting all persons against illegal acts, consistent with the high degree of responsibility required by their profession". ${ }^{27}$ Penegak hukum sepanjang waktu harus memenuhi kewajiban yang dibebankan kepadanya, dengan melayani masyarakat dengan melindungi semua orang dari perbuatan-perbuatan yang tidak sah, dan konsisten dengan tingkat pertanggungjawaban yang tinggi yang dipersyaratkan oleh profesi mereka.

Sosiolog Amerika, Talcott Parsons dalam karyanya berjudul The Professions and Social Structure pada tahun 1939 yang kemudian dimuat dalam buku kumpulan karangan berjudul "Essays in Soociological Theory" (1964),

\footnotetext{
${ }^{24}$ Soerjono Soekanto,(1983), Beberapa Permasalahan Hukum Dalam Kerangka Pembangunan Di Indonesia, UI-Press, Jakarta, hlm.3.

${ }^{25}$ Mardjono Reksodiputro, "Reformasi Hukum di Indonesia", Seminar Hukum Nasional Ke VII, BPHN Departemen Kehakiman dan HAM, 1999, hlm.73-87.

${ }^{26}$ Ibid.

${ }^{27}$ Ibid.
} 
berdasarkan studi komparatif terhadap struktur-struktur masyarakat dari sejumlah peradaban yang terpenting menyatakan bahwa "...the professions occupy a position of importance in our society which is, .... unique in history. ${ }^{128}$

Terdapat aspek-aspek terpenting dari tatanan masyarakat sangat tergantung pada berfungsinya profesi-profesi dengan baik, yang merupakan rangkaian aktivitas pengembangan dan penerapan ilmu yang dilaksanakan dalam suatu konteks profesional. Profesi-profesi dalam sistem sosial okupasi (pekerjaan) pada masyarakat modern menempati kedudukan yang sangat strategis, sehingga Parsons mengatakan "...it is difficult to imagine how it could get along without basic structural changes if they were seriously impaired. ${ }^{129}$

Pengamatan di bidang kesehatan, menunjukkan bahwa pengemban profesi kedokteran sering menyebabkan bekas pasien atau keluarga pasien menggugat dokter ke pengadilan dengan tuntutan perdata-ganti rugi yang sangat besar, atau bahkan ke ranah pidana. Hal ini menyebabkan para dokter berusaha melindungi diri dengan menjalankan defensive medicine, yang kesemuanya pada akhirnya mengakibatkan biaya pelayanan kesehatan menjadi sangat mahal dan tidak terjalinnya komunikasi yang baik antara dokter dan pasien. Hal ini menunjukkan bahwa pengembanan profesi kedokteran tengah mengalami gangguan yang cukup serius. Dalam bidang hukum, gejala merosotnya pengembanan profesi hukum tampak dari munculnya istilah "Mafia Peradilan", dan masyarakat mulai merasa bahwa sebaiknya untuk menyelesaikan suatu kasus sedapat mungkin jangan mencari bantuan pengemban profesi hukum (advokat).

Pandangan masyarakat juga tertuju bagi pengemban profesi lainnya, seperti profesi dokter, profesi guru-dosen, profesi akuntan dan profesi minister (ulama) dan lainnya ${ }^{30}$, seiring dengan fenomena terungkapnya penyimpanganpenyelewengan para pengemban profesi, menjurus kepada hilangnya kepercayaan masyarakat terhadap hukum.

\footnotetext{
${ }^{28}$ Talcot Parson, Essays in Sociological Theory, Revised Edition, The Free Press, New York,1964, hlm.35

${ }^{29}$ Ibid.

${ }^{30}$ Soemarno P. Wirjanto, (1980), Ilmu Hukum Profesi, ProJustitia No. Ke-11, Bandung, hal. 849.
} 


\section{B. Permasalahan}

1. Bagaimanakah peran etika profesi hukum dalam upaya pemberantasan kejahatan?

2. Bagaimanakah efektivitas etika profesi hukum dalam menanggulangi kejahatan yang timbul lingkungan profesional?

\section{Metode Penelitian}

Menggunakan metode penelitian kepustakaan ( library research), yaitu metode yang digunakan dengan cara mempelajari buku literatur, peraturan perundangan dan bahan-bahan tertulis lain yang berhubungan dengan materi pembahasan.

\section{PEMBAHASAN}

\section{Peran Etika Profesi Hukum Dalam Upaya Pemberantasan Kejahatan}

De Vos, ${ }^{31}$ merumuskan etika sebagai: “...ilmu pengetahuan tentang kesusilaan (moral).” Rumusan ini memang sangat singkat, dan menimbulkan dua pertanyaan: pertama: apakah ilmu pengetahuan itu, kedua: apakah kesusilaan itu? Jawaban dari dua pertanyaan tersebut di atas, secara lengkap terdapat dalam filsafat $^{32}$ yang membahas tentang ilmu (filsafat ilmu) dan etika (filsafat moral). Menurut Poedjawijatna ${ }^{33}$, istilah pengetahuan (knowledge) tidak sama dengan ilmu (science).

Kebanyakan pengetahuan diperoleh dari pengalaman inderawi manusia, dapat berasal dari pengalaman sendiri atau dari orang lain, biasanya digunakan untuk keperluan hidup sehari-hari atau sekedar untuk tahu. Sedangkan ilmu, lebih

\footnotetext{
${ }^{3131}$ De Vos, (2002), Pengantar Etika, Yogyakarta, PT.Tiara Wacana, hlm.1

${ }^{32}$ Filsafat itu datang sebelum dan sesudah ilmu. Dikatakan sebelum ilmu, karena semua ilmu yang khusus, seperti yang banyak terdapat dewasa ini, bermula sebagai bagian dari filsgai ilmu penafat, dikatakan datang sesudah ilmu, karena semua ilmu menghadapi pertanyaan-pertanyaan yang melewati batas spesialisasi mereka, kemudian ditampung oleh filsafat, dalam sejarah terdapat filsuf terkemuka di dunia, sekaligus adalah ilmuwan-ilmuwan besar seperti Aristoteles, Rene Descartes, Auguste Comte, Hegel, Leibniz, Pascal, Hume, Immanuel Kant, Einstein dan lainnya.

${ }^{33}$ Poedjawijatna,I.R.,(1986), Pembimbing ke Arah Alam Filsafat, Cet.ke-7, Jakarta, Bina Rupa Aksara, hlm.4-5
} 
jauh daripada itu. Ilmu ialah pengetahuan yang memiliki obyek, metode, dan sistematika tertentu, dan bersifat universal. ${ }^{34}$

Sedang kesusilaan, mengatur perilaku manusia serta masyarakat. Dapat dikatakan bahwa manusia dibentuk oleh kesusilaan, mengandung arti kehidupan alaminya mendapatkan pembatasan, disalurkan atau dibentuk oleh aturan-aturan yang telah disepakati, dalam bentuk tertulis ataupun tidak. Dengan demikian, etika dapat dikatakan sebagai ilmu pengetahuan yang membicarakan kesusilaan secara ilmiah.

Menurut Magnis, ${ }^{35}$ etika dalam arti yang sebenarnya adalah filsafat mengenai bidang moral. Jadi etika merupakan ilmu atau refleksi sistematik mengenai pendapat-pendapat, norma-norma, dan istilah-istilah moral. Dalam arti yang lebih luas, yaitu sebagai keseluruhan norma dan penilaian yang dipergunakan oleh masyarakat yang bersangkutan untuk mengetahui bagaimana manusia seharusnya menjalankan kehidupannya. Roscoe Pound, di dalam bukunya The Lawyer From Antiquity to Modern Times menyatakan bahwa “...The word (proffesion) refers to a group of men pursuing a learned art as common calling in the spirit of a public service because it may incidentally be a means of liverlihood". 36

Pengertian profesi-profesional dan profesionalisme, saat ini menjadi semacam istilah kunci dalam kehidupan modern, dengan tanpa mengetahui maksud-dan juga sikap atau orang profesional serta profesionalisme.

Menurut Sonny Keraf, ${ }^{37}$ profesi dapat dirumuskan sebagai pekerjaan yang dilakukan sebagai nafkah hidup dengan mengandalkan keahlian dan ketrampilan yang tinggi dan dengan melibatkan komitmen pribadi (moral) yang mendalam. Dengan demikian orang profesional adalah orang yang melakukan suatu pekerjaan purna waktu dan hidup dari pekerjaan itu dengan mengandalkan keahlian dan ketrampilan yang tinggi serta punya komitmen pribadi yang mendalam atas

\footnotetext{
${ }^{34}$ Darji Darmodihardjo,(2002), Pokok-Pokok Filsafat Ilmu, Jakarta, PT.Gramedia Pustaka Utama, hlm.2

${ }^{35}$ Franz Magnis Suseno,(2001), Etika Jawa, Sebuah Analisa Falsafati Tentang Kebijaksanaan Hidup Jawa, Jakarta, PT.Gramedia Pustaka Utama, hlm.6

${ }^{36}$ Ibid.

${ }^{37}$ Sonny Keraf,(2003), Etika Bisnis, Yogyakarta, Penerbit Kanisius, hlm.35
} 
pekerjaannya. Komitmen pribadi inilah yang melahirkan tanggung jawab yang besar dan mendalam atas pekerjaannya.

Komitmen moral ${ }^{38}$ ini kemudian dituangkan dalam bentuk aturan khusus yang menjadi pegangan bagi setiap orang yang mengemban profesi yang bersangkutan, yang biasanya disebut sebagai kode etik. Kode etik profesi merupakan norma yang ditetapkan dan diterima oleh sekelompok profesi yang mengarahkan atau memberi petunjuk kepada anggotanya bagaimana membuat dan sekaligus menjamin mutu profesi itu di masyarakat.

Bertumpu pada pandangan Roscoe Pound dan Talcott Parsons, dapatlah dirumuskan pengertian profesi sebagai berikut: profesi adalah pekerjaan tetap berupa karya pelayanan (service occupation) yang pelaksanaannya dijalankan dengan menerapkan pengetahuan ilmiah dalam bidang tertentu yang pengembanannya dihayati sebagai suatu panggilan hidup dan terikat pada etika umum dan etika khusus (yakni etika profesi) yang bersumber pada semangat pengabdian terhadap sesama manusia demi kepentingan umum, serta berakar dalam penghormatan terhadap martabat manusia.

Dalam pengertian tadi, maka profesi itu adalah suatu fungsi kemasyarakatan tertentu yang perwujudannya mensyaratkan penerapan (aplikasi) disiplin ilmu tertentu. ${ }^{39}$

Etika profesi pada dasarnya mengandung nilai-nilai yang memberikan tuntutan tingkah laku, demikian juga hukum. Lebih lanjut apabila dibanding-kan, hukum menghendaki agar tingkah laku manusia sesuai dengan aturan hukum yang diterapkan. Sedangkan etika mengejar agar sikap batin manusia berada dalam kehendak batiniah yang baik. Secara umum masyarakat kita mengharapkan orang untuk melakukan sesuatu yang benar, termasuk memenuhi tugas-tugas moral mereka, yaitu kewajiban-kewajiban yang bersesuaian dengan perasaan dasar

\footnotetext{
${ }^{38}$ Ukuran moralitas suatu perbuatan, baik atau buruk, ditentukan oleh dua faktor, yakni ukuran subyektif dan ukuran umum atau obyektif berlandaskan kepada norma-norma tertentu. Hati nurani seseorang secara subyektif memberitahukan kepada dirinya mana yang baik dan mana yang buruk. Norma-norma secara umum memberitahukan kepada semua orang tentang perbuatan yang baik dan buruk. Lihat, Martin Basiang, Law Dictionary, First Edition, Red \& White Publisihing, Jakarta.

${ }^{39}$ Sidharta,(2006), Moralitas Profesi Hukum, Bandung,hlm.
} 
manusia mengenai benar salah (sense of right and wrong) di mana orang harus mengikutinya. ${ }^{40}$ Perasaan dasar manusia mengenai benar salah ini ada yang mengkualifikasikannya sebagai hati nurani. Di sini yang dituju bukan terpenuhinya sikap perbuatan lahiriah akan tetapi sifat batin manusia yang bersumber pada hati nurani, karena itu diharapkan terciptanya manusia berbudi luhur.

Kode etik profesi hukum merupakan bentuk realisasi etika profesi hukum yang wajib ditaati oleh setiap profesional hukum yang bersangkutan, merupakan manifestasi konkrit dari kode etik adalah terlaksananya pedoman atau tuntunan tingkah laku yang sudah disepakati dalam upaya pelayanan kepada masyarakat.

Dapat dipertegaskan lagi antara hukum dan etika profesi mempunyai persamaan dan perbedaan. Persamaan dua-duanya memiliki sifat normatif dan mengandung norma-norma etik, bersifat mengikat. Di samping itu mempunyai tujuan sosial yang sama, yaitu agar manusia berbuat baik sesuai dengan norma masyarakat, dan bagi siapa yang melanggar akan dikenai sanksi. Adapun perbedaannya, mengenai sanksi dalam etika profesi hanya berlaku bagi anggota golongan fungsional tertentu/anggota suatu profesi. Sanksi hukum berlaku untuk semua orang dalam suatu wilayah tertentu, semua warga negara/ masyarakat. Apabila terjadi pelanggaraan dalam etika profesi ditangani oleh perangkat dalam organisasi profesi yang bersangkutan, misalnya oleh Majelis Kehormatan.

Pelanggaran dalam bidang hukum, hal ini dapat dilihat dengan adanya peraturan-peraturan mengenai profesi pada umumnya mengundang hak-hak yang fundamental dan mempunyai aturan-aturan mengenai tingkah laku dalam melaksanakan profesinya, terwujud dalam Kode Etik Profesi sebagai keharusan, kewajiban. Dengan demikian ketentuan dalam kode etik dapat dikualifikasikan sebagai normatif etik yang mempunyai kaitannya dengan hukum, dan mengandung ketentuan-ketentuan mengenai : (1) Kewajiban pada diri sendiri, (2) Kewajiban pada masyarakat umum, (3) Kewajiban kerekanan, (4) Kewajiban pada orang ataupun profesi yang dilayani.

\footnotetext{
${ }^{40}$ Richard G. Singer dan John Q. La Fond,(2007), Criminal Law, 4th ed, Aspen Publisher, New York, hlm. 41
} 
Adanya hubungan antara hukum dan etik, misalnya mengenai ketentuan etika profesi yang mengharuskan profesi tertentu menyimpan rahasia, tercantum dalam ketentuan dalam hukum (Pasal 170 KUHAP) dan membocorkan rahasia tersebut merupakan tindak pidana (Pasal 322 KUHP). Dengan adanya tindakan pemegang profesi sebagai malapraktik membawa konsekuensi penanganan/penindakan berdasarkan disiplin organisasinya maupun hukum. Dalam hal penindakan menurut hukum meliputi dari sisi hukum perdata, hukum pidana, maupun hukum administrasi.

Kode etik diharapkan dapat mengimbangi segi negatif profesi dan dengannya kepercayaan masyarakat akan suatu profesi dapat diperkuat, karena setiap klien memiliki kepastian bahwa kepentingannya akan terjamin. Supaya kode etik berfungsi dengan baik, kode etik harus menjadi self-regulation (pengaturan diri) dari profesi dan pelaksanaannya diawasi terus-menerus. ${ }^{41}$

\section{Efektivitas etika profesi hukum dalam menanggulangi kejahatan yang timbul di lingkungan profesional}

Usaha pemberantasan kejahatan telah dan terus dilakukan oleh semua pihak, baik Pemerintah maupun masyarakat, karena setiap orang mendambakan kehidupan bermasyarakat yang tenang dan damai. Namun di negara maupun kejahatan selalu dapat saja terjadi, sepanjang dalam negara itu hidup manusiamanusia yang mempunyai kepentingan yang berbeda dan berpotensi terjadinya benturan satu dengan yang lain (conflict of interest).

Mencegah kejahatan berarti menghindarkan masyarakat dari jatuhnya korban, penderitaan serta kerugian lainya. Meskipun dalam hal pencegahan ini tugas pada penegak hukum, dalam menjalankan tugas dan fungsinya tidaklah begitu mudah dalam menangani baik terhadap pelaku maupun korban dari terjadi kejahatan. Apabila kepercayaan masyarakat terhadap penegakan hukum itu mencapai tingkat kritis, kecenderungan reaksi sosial terhadap kejahatan mengambil bentuk upaya-upaya perlindungan diri secara kolektif dengan mengembangkan prasangka-prasangka sampai ke tindakan-tindakan yang sama kerasnya dengan kejahatan itu sendiri. Keadaan inilah yang dijaga agar tercipta

${ }^{41}$ K.Berten, hlm.280 
untuk menemukan alternatif yang tepat dalam menghadapi kejahatan/penjahat karena adanya kesulitan-kesulitan untuk mengembangkan hukum pidana yang bersifat dogmatik dan sekaligus mempunyai sifat praktis untuk menghadapi kejahatan dan penjahat, yang bisa terwujud melalui tertib sosial. Suatu dilema antara kepentingan tertib sosial dan kepentingan peranan hukum. ${ }^{42}$

Pelaksanaan hukum dalam kehidupan masyarakat mempunyai arti yang sangat penting karena apa yang menjadi tujuan hukum justru terletak pada pelasanaan hukum itu. ${ }^{43}$ Hubungan antara tertib sosial dan faktor normatif sebagai salah satu instrumen, menjelma menjadi tertib hukum, di samping kepentingan kehidupan masyarakat untuk tertib di bidang politik, ekonomi, hankam, budaya dan lainnya.

Dewasa ini sangat dirasakan perkembangan akan delik-delik khusus di lingkungan profesi yang penjahatnya dinamakan professional fringe violator. ${ }^{44}$ Kategori penjahat ini selalu melibatkan keahlian di dalam aksinya, baik dalam bentuk internasional, kealpaan, dolus aventulis maupun pelanggaran hukum disiplin profesional. Jenis kejahatan di atas perlu mendapatkan perhatian yang serius, sebab dimensi viktimologisnya sangat besar. Yang dirugikan tidak hanya kliennya saja, tetapi masyarakat dan negara dalam kaitannya dengan kebijaksanaan pembangunan (public policy) serta organisasi profesinya. Di sinilah pentingnya standard of professional dipermasalahkan.

Perbuatan harus diukur dengan kriteria-kriteria yang objektif dan memperhatikan pertama, profesional diharapkan untuk menguasai dan mempraktekkan ketrampilan dan pengetahuan profesinya dengan sebaik-baiknya; kedua, penilaian dilakukan atas dasar standar profesi yang berlaku di lingkungan profesinya, dimana standar profesi ini harus dilihat secara dinamik. Karena dalam hal-hal tertentu (misalnya di dunia medis), maka kesaksian ahli dalam pembuktian

\footnotetext{
${ }^{42}$ Livia V.Pelle, (2012), Peranan Etika Profesi Hukum, Lex Crimen Vo.I,No.3,2012

${ }^{43}$ Riduan Syhrani,(2011), Rangkuman Intisari Ilmu Hukum, PT Citra Aditya Bakti, Bandung, hal.181

${ }^{44}$ Gibbons,(1987), Society, Crime and Criminal Carers, Prentice Hall of India. New Delhi, hlm. 344 .
} 
kesalahan menjadi sangat penting untuk menjaga keseimbangan, keselarasan, dan keserasian antara public order, legitimation and competence.

Kebijakan untuk mengatasi persoalan-persoalan yang berkaitan dengan kejahatan di lingkungan profesional harus ditempuh secara komprehesif dan multi dimensional. Terkait di sini di samping masalah hukum, juga masalah-masalah etik/moral, bahkan juga bersifat ekonomis.

Pengendalian internal sangat penting untuk memberikan perlindungan bagi entitas terhadap kelemahan serta untuk mengurangi kemungkinan kesalahan dan tindakan yang tidak sesuai dengan aturan, sehingga pengendalian yang efektif dapat mempertahanakan perilaku etis seseorang sehingga tidak mengakibatkan kerugian.

Mengadopsi Sistem pengendalian internal sebuah perusahaan, terdiri dari kebijakan dan prosedur yang dirancang untuk memberikan manajemen kepastian yang layak bahwa entitas telah mencapai tujuan dan sasarannya. Manajemen bertanggung jawab untuk menetapkan dan menyelenggarakan pengendalian entitas. Jika suatu sistem pengendalian internal lemah maka akan mengakibatkan kekayaan perusahaan tidak terjamin keamanannya, informasi yang ada tidak teliti dan tidak dapat dipercaya, tidak efisien dan efektifnya kegiatan-kegiatan operasional perusahaan serta tidak dipatuhinya kebijaksaan manajemen yang ditetapkan. Dengan adanya pengendalian wewenang oleh pemilik kepada pengelola, maka fungsi pengendalian semakin bertambah penting. Pengendalian internal yang dirancang sedemikian rupa untuk memonitoring akan dapat mempertahankan perilaku etis profesional dalam menjalankan tugasnya. Sehingga tindakan yang dapat merugikan suatu entitas dapat diminimalisir atau bahkan terbebas dari perilaku yang tidak etis. ${ }^{45}$

Penelitian Husein (2008) ${ }^{46}$ menjelaskan salah satu faktor yang mempengaruhi perilaku tidak etis yaitu pemahaman kode etik. Hal ini dikarenakan etika seharusnya meliputi proses penentuan yang kompleks, mengenai apa yang harus dilakukan seseorang dalam situasi yang ada, kesimbangan dari

\footnotetext{
45 Agus Raharjo,dkk.,(2011), Profesionalisme Polisi dalam Penegakan Hukum, Jurnal Dinamika Hukum, vol.11,No.3,hlm.397

${ }^{46}$ Ibid.
} 
pertimbangan sisi dalam dan sisi luar yang disifati oleh masing-masing kombinasi pengalaman dan pembelajaran dari tiap individu. Jika seseorang memahami kode etik dengan baik maka dapat menghilangkan atau meng-hindari konflik yang dapat mempengaruhi profesionalitas.

Setiap bidang profesi dituntut untuk berperilaku etis. Namun persepsi perilaku etis tersebut terkadang sangat sulit untuk dijelaskan, maka dari itu perlunya aturan-aturan khusus pada setiap profesi. Aturan khusus pada profesi terdapat dalam kode etik profesi yang memuat nilai etika profesi dalam semua bidang profesi. Etika profesi bagi profesional terdiri dari beberapa prinsip yaitu tanggung jawab, kepentingan publik, integritas, objektivitas, kompetensi dan kehati-hatian profesional, kerahasiaan, perilaku profesional dan standar teknis.

Pengetahuan akan prinsip-prinsip etika ini akan memberikan pemahaman yang akan berpengaruh pada perilaku salah satunya prinsip kepentingan publik, pengorbanan kepentingan seseorang untuk kepentingan bersama tidak hanya benar dan memberikan suatu nilai bagi individu tetapi baik untuk entitas profesi yang bersangkutan.

\section{KESIMPULAN}

Terdapat dua simpulan yang dapat diberikan berdasar pada permasalahan, hasil dan pembahasan sebagaimana tersebut di atas:

Pertama, profesi adalah pekerjaan tetap berupa karya pelayanan (service occupation) yang pelaksanaannya dijalankan dengan menerapkan pengetahuan ilmiah dalam bidang tertentu yang pengembanannya dihayati sebagai suatu panggilan hidup dan terikat pada etika umum dan etika khusus (yakni etika profesi) yang bersumber pada semangat pengabdian terhadap sesama manusia demi kepentingan umum, serta berakar dalam penghormatan terhadap martabat manusia, yang dituju bukan terpenuhinya sikap perbuatan lahiriah akan tetapi sifat batin manusia yang bersumber pada hati nurani, karena itu diharapkan terciptanya manusia berbudi luhur. Diperlukan aturan-aturan khusus pada setiap profesi, yaitu 
tanggung jawab, kepentingan publik, integritas, objektivitas, kompetensi dan kehati- hatian profesional, kerahasiaan, perilaku profesional dan standar teknis. z

Kedua, perkembangan akan delik-delik khusus di lingkungan profesi, yang dalam melakukan kejahatannya selalu melibatkan keahlian untuk melakukan pelanggaran hukum disiplin profesional. Jenis kejahatan di atas perlu mendapatkan perhatian yang serius, sebab dimensi viktimologisnya sangat besar. Yang dirugikan tidak hanya kliennya saja, tetapi masyarakat dan negara dalam kaitannya dengan kebijaksanaan pembangunan (public policy) serta organisasi profesinya. Pentingnya standard of proffesional dengan memahami kode etik dengan baik diharapkan bisa menghilangkan atau menghindari konflik yang dapat mempengaruhi profesionalitas. Pengendalian internal yang dirancang sedemikian rupa untuk memonitoring akan dapat mempertahankan perilaku etis profesional akuntansi, diharapkan akan dapat meningkatkan pencegahan kejahatan profesi. 


\section{DAFTAR PUSTAKA}

Agus Raharjo,dkk.,(2011), Profesionalisme Polisi dalam Penegakan Hukum, Jurnal Dinamika Hukum.

Darji Darmodihardjo,(2002), Pokok-Pokok Filsafat Ilmu, Jakarta, PT.Gramedia Pustaka Utama

De Vos, (2002), Pengantar Etika, Yogyakarta, PT.Tiara Wacana

Franz Magnis Suseno,(2001), Etika Jawa, Sebuah Analisa Falsafati Tentang Kebijaksanaan Hidup Jawa, Jakarta, PT.Gramedia Pustaka Utama

Gibbons,(1987), Society, Crime and Criminal Carers, Prentice Hall of India. New Delhi

Livia V.Pelle, (2012), Peranan Etika Profesi Hukum, Lex Crimen Vo.I,No.3

Riduan Syhrani,(2011), Rangkuman Intisari Ilmu Hukum, PT Citra Aditya Bakti, Bandung

Richard G. Singer dan John Q. La Fond,(2007), Criminal Law, 4th ed, Aspen Publisher, New York

Sonny Keraf,(2003), Etika Bisnis, Yogyakarta, Penerbit Kanisius

Soemarno P. Wirjanto, (1980), Ilmu Hukum Profesi, ProJustitia No. Ke-11, Bandung

Sidharta,(2006), Moralitas Profesi Hukum, Bandung

Soerjono Soekanto,(1983), Beberapa Permasalahan Hukum Dalam Kerangka Pembangunan Di Indonesia, UI-Press, Jakarta

Talcot Parson, Essays in Sociological Theory, Revised Edition, The Free Press, New York, 1964

Mardjono Reksodiputro, Reformasi Hukum di Indonesia, Seminar Hukum Nasional Ke VII, BPHN Departemen Kehakiman dan HAM, 1999

Poedjawijatna,I.R.,(1986), Pembimbing ke Arah Alam Filsafat, Cet.ke-7, Jakarta, Bina Rupa Aksara 